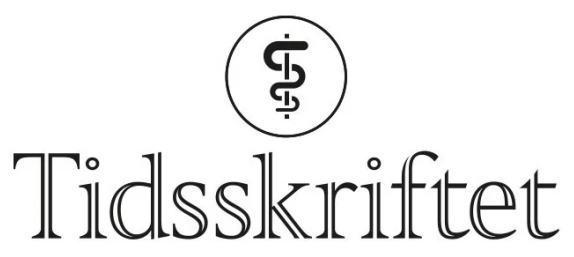

DEN NORSKE LEGEFORENING

\title{
Årvåkne leger gir bedre vaksinesikkerhet
}

LEDER

\section{PERNILLE HARG}

pernille.harg@legemiddelverket.no

Pernille Harg er cand.pharm. og seniorrådgiver innen legemiddelovervåking ved Statens legemiddelverk og møtende vararepresentant i den europeiske legemiddelsikkerhetskomiteen PRAC.

Forfatteren har fylt ut ICMJE-skjemaet og oppgir ingen interessekonflikter.

\section{Nyutviklete vaksiner mot covid-19 er tatt i bruk i stor skala. Spontanrapporter fra leger om mistenkte bivirkninger har sjelden hatt større betydning.}

Bare få dager etter de første internasjonale nyhetsoppslagene om alvorlig blodpropp etter vaksinering med AstraZeneca-vaksinen, ble det meldt flere lignende tilfeller i Norge $(\underline{1}, \underline{2})$. Observante leger reagerte på uventede og alvorlige sykdomsbilder hos i utgangspunktet friske helsearbeidere som nylig var vaksinert. Legene meldte dette som mulige bivirkninger via nettsiden melde.no og tok samtidig direkte kontakt med Legemiddelverket.

Etter et fatalt tilfelle av blodpropp i Danmark satte Folkehelseinstituttet raskt bruk av AstraZeneca-vaksinen på pause i Norge. Dette var samtidig som det første fatale tilfellet $\mathrm{i}$ Norge ble kjent (1). Pausen i vaksineringen ga myndighetene tid til å unders $\emptyset$ ke de norske tilfellene grundigere og samtidig mulighet til å få bedre oversikt over hva som var meldt i andre land. Gjennom den europeiske legemiddelsikkerhetskomiteen (PRAC) deltok de også i europeiske legemiddelmyndigheters felles utredning av denne nye problemstillingen.

Spontanrapportering, det vil si melding av mistenkte bivirkninger som avdekkes i klinisk praksis, er viktig for å overvåke sikkerheten ved bruk av legemidler og vaksiner. I Norge er vi heldige som har helsepersonell som tar denne oppgaven alvorlig og som har god meldekultur. Alle spontanrapporterte bivirkninger fra land i EU/EØS-området samles i en felles europeisk bivirkningsdatabase, EudraVigilance. Tilsvarende samles bivirkningsmeldinger fra hele verden i Verdens helseorganisasjons bivirkningsdatabase, VigiBase. I ukene som fulgte de første meldingene om mistenkte bivirkninger i form av blodpropp kombinert med lave blodplater, ble det meldt inn flere hundre slike tilfeller til disse bivirkningsdatabasene (3). Disse spontanrapportene, sammen med klinikeres og forskeres raske bidrag (2,, 4 .), ga et tilstrekkelig beslutningsgrunnlag for å gjøre 
regulatoriske endringer, dvs. å innføre nye forsiktighetsregler og beskrivelse av bivirkningene for AstraZeneca-vaksinen, senere også Janssen-vaksinen. Dette skjedde til tross for at man ennå ikke kjenner den bakenforliggende mekanismen fullt ut.

I løpet av få uker har vi fått ny kunnskap om tilstanden som nå betegnes som vaksineindusert trombotisk trombocytopeni (VITT) $(\underline{2}, 4,5)$ eller trombose med trombocytopeni-syndrom (TTS) (므). Tilstanden anses nå som utløst av vaksinasjon med to ulike virusvektorvaksiner, men bildet er komplekst. Det vil ta lang tid å avdekke detaljene. Det typiske bildet synes så langt å være tromboser på uvanlige lokalisasjoner kombinert med trombocytopeni. Tilstanden har oppstått hos unge, i all hovedsak friske personer uten åpenbare risikofaktorer. Hittil synes det å være flere kvinner enn menn som er rammet, og de fleste er under 60 år. Denne observasjonen må tolkes med varsomhet, ettersom AstraZeneca-vaksinen i EU/EØS-området i all hovedsak er gitt til personer under 65 år samt til helsepersonell og lærere, yrker der flertallet er kvinner.

Trombose med trombocytopeni-syndrom har kun fått en foreløpig definisjon, og det er fortsatt uklart om det finnes ulike grader - eller et kontinuum - av tilstanden. Noen pasienter får et svært alvorlig, og dessverre også fatalt, forløp. Så lenge syndromet ikke er fullstendig kartlagt, har bivirkningsmeldinger om elementer av dette sykdomsbildet, slik som blødning og blodpropp med eller uten lave blodplater, stor verdi (7.).

\section{«Spontanrapporter fra leger $i$ Norge har $i$ stor grad bidratt til at sammenhengen mellom vaksinen og det alvorlige sykdomsbildet ble oppdaget så raskt som det gjorde»}

Spontanrapporter fra leger i Norge har i stor grad bidratt til at sammenhengen mellom vaksinen og det alvorlige sykdomsbildet ble oppdaget så raskt som det gjorde. Melding av bivirkninger gjøres fortrinnsvis via nettsiden melde.no. Jo mer detaljert beskrivelse som gis av hendelsen og omstendighetene rundt, jo større verdi har meldingen.

Legemiddelmyndighetene har overvåkingsansvaret for vaksinene, men står nesten uten verktøy for raske tiltak dersom helsepersonell ikke er observante og melder mistenkte bivirkninger. Alle spontanrapporterte bivirkningsmeldinger havner i

Bivirkningsregisteret, som nylig har blitt et nasjonalt helseregister som vil kunne sammenstilles med andre helseregistre. I tillegg til et godt meldesystem er helsevesenet i Norge organisert slik at vi lettere kan oppdage opphopning av spesielle sykdomstilfeller, slik som trombose med trombocytopeni-syndrom, fordi disse pasientene i stor grad behandles ved få og spesialiserte avdelinger.

«Tenk bivirkning - meld bivirkning»

Overvåkingssystemet går på «høygir» nå under pandemivaksineringen, men spontanrapporteringssystemet er i bruk for alle legemidler, alltid. Dette sikrer at nytten av legemidlene i alminnelig bruk oppveier risikoen, også over tid. Oppfordringen er derfor: Tenk bivirkning - meld bivirkning! Dette gjelder særlig ved oppstart av nye legemidler, ved doseøkning eller andre endringer i legemidler. Hensikten med systemet er å avdekke bivirkninger som er nye og ukjente. Da kan du ikke forvente å være sikker på årsakssammenheng før du melder, du må melde ut ifra mistanke.

\section{LITTERATUR}

1. Bjørnstad-Tuveng TH, Rudjord A, Anker P. Fatal hjerneblødning etter covid-19-vaksine. Tidsskr Nor Legeforen 2021; 141. doi:10.4045/tidsskr.21.0312. [PubMed][CrossRef] 
2. Schultz NH, Sørvoll IH, Michelsen AE et al. Thrombosis and Thrombocytopenia after ChAdOx1 nCoV-19 Vaccination. N Engl J Med 2021; 384: NEJMoa2104882. [PubMed][CrossRef]

3. Cines DB, Bussel JB. SARS-CoV-2 Vaccine-Induced Immune Thrombotic Thrombocytopenia. N Engl J Med 2021;384: NEJMe2106315. [PubMed][CrossRef]

4. Greinacher A, Thiele T, Warkentin TE et al. Thrombotic Thrombocytopenia after ChAdOx1 nCov-19 Vaccination. N Engl J Med 2021;384: NEJMoa2104840. [PubMed][CrossRef]

5. Sørvoll IH, Horvei KD, Ernstsen SL et al. An observational study to identify the prevalence of thrombocytopenia and anti-PF4/polyanion antibodies in Norwegian health care workers after COVID19 vaccination. J Thromb Haemost 2021; 19: jth.15352. [PubMed][CrossRef]

6. Brighton Collaboration. Interim Case Definition of Thrombosis with Thrombocytopenia Syndrome (TTS). https://brightoncollaboration.us/thrombosis-with-thrombocytopenia-syndromeinterim-case-definition/ Lest 3.5.2021.

7. Haakonsen HB, Nystedt A. Dyp venetrombose mer enn to uker etter vaksinering mot covid-19. Tidsskr Nor Legeforen 2021; 141. doi: 10.4045/tidsskr.21.0274. [PubMed][CrossRef]

Publisert: 12. mai 2021. Tidsskr Nor Legeforen. DOI: 10.4045/tidsskr.21.0368

(C) Tidsskrift for Den norske legeforening 2023. Lastet ned fra tidsskriftet.no 26. april 2023. 